maanjaabramovic@gmail.com

https://doi.org/10.18485/rit.2021.19.35.10

\title{
THE SERBIAN ORTHODOX REFUGEES: ANALYSIS OF NARRATIVE ${ }^{1}$
}

\begin{abstract}
Summary:
The study deals with the renewal of collapsed orthodox identity of refugees. Orthodox social support is a crucial aspect of overcoming trauma. Refugees are identified with religious officials of the Orthodox Church. Integration within religious community provides security, acceptance and release from fear. Using the analysis of narrative we try to look deeper into cultural shock, psychological trauma and spiritual transformation of refugees.
\end{abstract}

Key words: narrative, war, memories, Orthodoxy, refugees

\section{Introduction}

Today analysis of narrative is more popular then analysis of discourse in the examinations about people who live on margins (Sremac 2010a; Pavlović i dr. 2006). Narrative can explain us war, fall of ecumenism, demonstrations and victims. Narrative can tell us about their ,new life" in Serbia, how refugees become devotional and how priests help refugees to became more open and involved within the church life. In Serbia refugees find jobs and became part of society. Religion is a key point in constructing the new cultural identity. Questions in this study are about new identity, how war makes people more religious and how society accepts refugees. I hope that this study will help refugees and those ones who want to understand them.

\section{Methodology}

The goal of this study is positive side of trauma and psychological progress of refugees. The refugees have a negative psychological consequences like memories, fears and nightmares. Research was being conducted from October 2013

1 This paper was presented at the International Scientific Conference 'Global and Regional Aspects Of Migrant Crisis and Social Consequences of Brain Drain on the Development of Serbia and the Balkans' held on 28 May 2016 at the SANU and University of Niš 
until March 2014. We need about six months to collect data, because some informants didn't want to tell their stories. Each story lasted about an hour, but some stories last for about 3 hours. Sometimes we needed a break when the informants themselves wanted to have it. We recorded stories from 3 countries. Target population was 7 Yugoslav refugees from Bosnia, Serbia and Croatia. The refugees were aged between 27 and 64 years old. The research was located in Belgrade.

\section{Post Traumatic Stress Disorder (PTSD)}

Post Traumatic Stress Disorder (PTSD onwards) is defined as an anxiety disorder that can be developed as a result of the traumatic experience. Only $12 \%$ of the population is predisposed to PTSD. Depending on the degree of exposure can cause depression and sometimes neurosis. PTSD assumes the part of life which differs from normal conditions of life, and it is linked to accident such as war, loss of spouse, death of a family member and it is associated to destructiveness (Жикић 2011: 790). With refugees it includes: war, armed conflict, religious and ethnic persecution, poverty, physical danger, possibility of losing his/her own life, watching the murder of friends, isolation, stigmatization and social exclusion (ibid: 799). Victims are generally not able to interpret to themselves their own traumatic narration (Sremac and Beuk 2010b: 269). The word means a trauma incident, emotionally painful experience, and it is divided into individual (the loss of a child, sexual abuse, traffic accidents) and collective (war and genocide) (ibid:272). The same authors argue that women in faith have a lower degree of PTSD than nonbelievers (ibid: 274). PTSD is followed by positive changes such as improvment of interpersonal relationships, greater appreciation of life, spirituality and higher productivity (ibid: 276).

\section{Theoretical framework}

Narrative of informants gave us information about their identity and spiritual transformation. The narrative through religious prism turns their war trauma into events which are beneficial for their lives. Narrative construction of identity improves every day, so they can tell about themselves from the best angle. Through narrative their stories always remind us that they are stigmatized. Authors who had studied refugees told us that they do not feel themselves as a part of society (Жикић 2011:783). Problems are poverty and isolation. The isolation includes 
institutions, culture and space. Their public and private life includes trauma because of the lack of money, isolation and stigma identity (ibid: 790). Future research ought to find out their point of view and reasons for their reactions. Fieldwork is necessary but it's hard to find the informants. They don't want to be identified with others refugees (Жикић 2007:39). Population of Serbia had a certain distance towards the refugees than before and culture shock returned towards solidarity. Srđan Sremac and Sergej Beuk said that a starting point of research is facing religion to trauma (Sremac and Beuk 2010: 271). Their oppinion is that suffering changes into paradise and with trauma they become more devoted (Ibid). The authors further state that only those who suffer according to Jewish and Christian religion of their state are replaced to paradise (ibid). It is known that during the crisis in the life of that individual or the whole of society turn to religion, although the basic needs may be unclear or even suppressed (ibid). The authors claim that the subject is unable to explain to himself/herself the trauma, and that the religious significance is bringing trauma to an end, and eventually transforming it into a meaningful event that has positive ends (ibid). They claim that trauma does not lead to pathology, but rather is a turning point that leads to spiritual and psychological development (ibid: 272-276). Srđan Sremac and Sergej Beuk give the division of trauma symptoms into the emotional and psychological (ibid: 281). Emotional include: shock, disbelief, anger, irritability, guilt, shame, self-blame, sadness, hopelessness, confusion, anxiety, fear, withdrawal and isolation, while psychologically it includes: insomnia, nightmares, palpitations, lability, fatigue and tension (ibid ). The authors state that the need for psychoactive substances can occur (ibid: 282). Zorica Kuburic states that the self-esteem and confidence in other people are the most important prerequisites of mental health (Kuburić 2010a: 359). The author studied the degree of trust between the Orthodox, Protestants, Catholics and Muslims in Croatia, Bosnia, Kosovo and Bulgaria, and found that the nation divided within itself about $50 \%$ of those who are open to others, and $50 \%$ of those who do not accept the other (ibid: 364-365). The research project Life in post-war communities has assembled a team of scientists who dealt with refugees, their mental health, their rights, current conditions of life and property. The authors have studied the Yugoslav wars in the period from 1991 to 1999, including 4 wars: the war in Slovenia (27 June-7 July 1991), the war in Croatia (1991-1995), the war in Bosnia and Herzegovina (1992-1995) and the war between NATO and Serbia and Montenegro (1999). The authors have studied and all possible forms of pressure, intimidation, discrimination, humiliation and misery of war refugees in ethnically mixed terri- 
tories (Opačić et al. 2005: 15-16). Moreover, the authors were statistically dealt with: housing status, income, employment and non-mental disorder of refugees (ibid: 56-150). The authors note that PTSD affects strongly on collapse of physical health condition and that can cause hypersensitivity to negative events, falling into a vicious circle and increase psychopathology (ibid: 153). Appendix to trauma can be caused by refugees themselves in acts such as drug and alcohol abuse, cigarette smoking or poor nutrition (ibid). The authors state that PTSD is 'a normal reaction to abnormal events' regardless of gender, age and race (ibid: 154). What happens after the stress is the loss of self-esteem and lowering the socio-economic scale (ibid: 156). The transition to the new environment, from rural to urban and vice versa, can also cause anxiety and depression (ibid). Low self-esteem is projected identically in the evaluation of other people and not having life satisfaction in general (ibid: 157). Returnees always have a better picture of themselves from refugees (ibid: 164). The most important conclusions of these authors were that $\mathrm{BiH}$ and $\mathrm{SCG}$ are among ten countries with the largest number of refugees (ibid: 183), then itenegration into society declines psychopathology (ibid: 185). Saša Nedeljković in book Honour, blood and tears discuss about ethnos of tribe (Nedeljković 2007:12). In New Testament ethnos is identified with others: non Jews and pagans (Ibid:13). As the time passes, ethnos is identified with horde, brotherhood, people and nation (Ibid:16). A few communities can be parts of one nation and one community can have a few nations (Ibid:18). Nations are divided in ethnic (traditional culture) and western model of state (Ibid:19). An ethnic group is a form of social integration that works on the principle of binding friends subordinate to leader who are willing to confront enemy (Ibid: 24). After analog and digital principle of systematization, people are divided into internal positive, negative internal, external positive and negative external (Ibid: 28). The author states that the religious identity of the most important indicator of national identity, although it can stand alone (ibid: 255). Ger Dejzing in his book Religion and Identity in Kosovo explains that the people sold their property for a very low price, and in all ways they tried to return to their country, although they were not much appreciated in their own country (Dejzing 2005).

\section{Narrative identity during the war}

Personal narrative reveals a traumatic experience and disbelief that the war has started and it begins to threaten the sense of everyday life. The refugees were in disbelief and war perceived as a joke, comic book, movie or holidays. 
(...) Because I imagined war as a natural disaster, like an earthquake, when we to relocate the school! How small Đokica imagines the war, approximately! (Laughs)

We were in a Muslim neighborhood. You see people in uniforms, but I did not take it as a war but as a holiday where we can play.

We did not know what war was, so we bought canned meat. Comics.

I watched it on the movie, I laughed, and everything around you flew around and nothing hurt you, and I started to run and nothing happened to me. And it happened to me like on the movie, now when I think.

A war plot starts and informants lose the sense of life when around the town and in buses they see snipers and feel the tension because of shooting citizens. Although under the job duty, they realized that there is no more life there for them.

It was a sniper Juka Prazina and opened fire on the hikers, the Protestants.

All crises and problems positively transform the mind of its own shares from the reverse side of the enemy.

The child told me ,Dad, you led the Red Cross!' It was a sniper. We left and I knew we would never go back.

I had the urge to go out and to work together with them, demonstrate against the war. He went with me and my husband, and then we stopped, there was a huge flag, we carried that flag we're two went forward on the forehead and then we tell them, this, what shouting in Serbian, telling them, ,Peace Now!', then ,Drop your weapon! Drop your weapon!' and so on, and I know that some of my friends who were sitting in cafes where we went in amazement watching what we do, how much and in fact I had no desire to speak against the war!

After that, the resulting state of the besieged city, where anyone who approached the window, he could have been shot down, hit by snipers. Then we retreated sfrom the room so as not to hurt anyone, and we slept in the living room. A few nights it was just as severe, virtually created a state of emergency.

The informants feel disappointed and cheated. All information during the war was lies. While bombs and grenades were falling and while people were seeking shelter from snipers, on Sarajevo TV program song, Sarajevo, My Love, was shown. The refugees say that they couldn't said anything for media.

And then one, seems to have been a journalist asked me how I perceive and what is happening at that time in Sarajevo, how I survived and I want- 
ed something to tell him, but I was surrounded by some girls who are beginning to talk about how Sarajevo ideal for life, a story about brotherhood and unity, which is not true any more, but it was layering, and I told him then ,see, see that my freedom in Sarajevo, When I do not you can not give a statement that I will, than we fall into one word! „I later saw on TV that belonged to the Muslim movement, and apparently they were watching us, individuals who are there entered with them together and then they tried to make their version of the story of the Sarajevo send! Suddenly, the radio, the cells were that did not exist before, some radio $\mathrm{M}$ was in the same building where it will be later Children Embassy.

In Serbia on Kosovo terrorist attacks, roadblocks, the murder of police officers and civilians started to happen. One informant was a police officer and he says that the first victims were cops on Kosovo and priest on a wedding ceremony in Bosnia.

He married one of the priests and the wedding guests were supposed to have lunch in the old church on just the bazaar, but they made an ambush Green Berets Muslim forces.

(...) Then, intimidation of Albanians who were working in state institutions, or as they called them Serbian institutions, including murders, abductions and killing them, putting on the roads as an example that you should not be with Serbia, with the authorities. On the terrorist attacks our police had to respond, and the first strong conflict was in Likušanima where there were civilians, among them are also some women and children, they were not released from their home, it happened that should not have been, were utterly destroyed all in the blockade.

In Bosnia the first shoot was on Muslim religious holyday Bairam. It was very strange, because Muslims never celebrate religious holydays with shooting. Shooting was a sign that the war started. The informants tell that war was shift and that it was all about demonization of Serbs and glorifying of Muslims. Six months before the war started there was a gathering of black magic people in Sarajevo where Muslims prayed for beginning of the war. In Bosnia and on Kosovo everything was prepared for the beginning of the war and trigger situations were only needed to start the war and expelling Serbs from their homes. In Bosnia the trigger point was a conflict in Assembly and on Kosovo it was deaths of Albanians. The informants feel disappointed.

I worked essentially in the Children's Hospital and I say I have become a Member of it, through the project in January, a few months before this story, we had entered the Children's Embassy with this project. Then the Frenchman arrived in Sarajevo from Belgrade and one that led UNICEF and who came to welcome the establishment of the Children of the Em- 
bassy as well as non-governmental organizations and what shocked me at the time was that all the man later realized, mascot of Children's Embassy which has already been made, doll porcelain which was a child who is completely torn with broken flower in hand, meant a war victim. So, if you believe that there will be no war if you are not preparing for war, why do you say mascot, you know, war victim? Absolutely crazy! And what happens, I came from a night-shift, Frenchman and Duško Tomić, who led the embassy came to the reception and gave him a mascot in his hands and as he had not been well established, it fell onto the floor and broke into a thousand pieces! Can you imagine how horrible it looked! Children's body that creates the dissolution! And then starts a stupid story, it is when something breaks and so! As to shatter glasses! For me it was a symbol of the child who had died! So preparation was we were ready to start a war, and this war had started in rigged situation in the assembly there was a conflict, but there were some people as peacemakers, and some that were for war: war was still on the Serbian side, though the truth was not it! All were armed, they were all ready and guided from the outside. The war starts and they conduct it. The war was not spontaneously created but by conspiracy theory there were warlords! Now how to overcome the horror of war when a person understand the cause of such a mess in my head and in my soul, it was amazing! For me it was just a horror to learn that war was not something spontaneous, but that it actually provoked! Until then, I was not so experienced, I thought there was a conflict, people were actually here in our eyes pushed onto each other and the whole thing was rigged!And then it was clear that war start with the shooting, then we went to the children's embassy to arrange the evacuation, so the idea was a way of pediatrics, children, I imagined that planes and UNPF who came to Sarajevo and put on the planes and children went outside the war zone, all of them, school and classes.

We are fooled and we are afraid of fake situations!

When the Americans started to make the game of the war, where it was found 48 killed Albanians. According to some information of Norwegian scientists, It was established that these men were subsequently dressed, but this report came to light 12 years later. Americans had forced her to write this report. She admitted 4 years ago that the Americans forced her to write the report that The men were subsequently dressed in civilian clothes.

When situation became dangerous the informants took their children and bought tickets for Belgrade and Podgorica. Some parents tried to send their children a few times because they didn't want to be separated. The baggage consisted of photos, money, toys for children and memories. They packed baggage when they realized that there was no future for them there. Concept of ambiguity made refuges disappointed: killers were liberators, songs of love were played until peo- 
ple could be killed and children could be victims of war and fascist felt like antifascist. The spouses who were intermarriaged had two solutions: they divorced or ran away to some foreign countries. Children were coming in refugee columns. The cousins took care of children whose parents stayed in the war region till the new meeting with them.

We all have children to move out, because it was totally unsafe. We were under the job description, the children who had to guard. At half past eight, the first bomb was dropped, the evening with siren never stopped, non stop we were under threat. As the children no longer went to school since officially the bombing started, whoever had the kids where to send, we sent our to sister's in Belgrade. We stayed down there. We were separated for 77 days. We had not seen the children for almost 3 months.

The refugees who didn't have cousins went to camps. Adaptation was something that had to be done immediately.

\section{Identity, stigma and marginalization}

People in Serbia had very serious problems in accepting the refugees and this message reflected to their identity.

I've been always marked as a refuge!

I experience this all the time! One grandmother offended me by telling me that I should go back to where I came from!

For me it's not normal when my colleague says that he took her a workplace. In one occasion she said why we were unhappy when we got the job. My company was the central in Belgrade. They gave me a job in the service where I worked! She insulted us that they gave us, I had not come from another country! Someone says!; Those refugees came with a lot of money and bought everything!; The country had done its job for me. We were all housed.

I found a job in Požarevac. The General manager says' Tell them you're Sremac. It was obvious that the did not like me at all. I wanted to open an account, I should have received a salary and they say (imitating the accent) Director, can refugees open an account for a salary? „, People did not understand our situation, and thanks God that they did not!

The life of refugees was somewhere between ,here' and ,there' because they came in Serbia from ,nowhere'. The refugees left their jobs and came to Serbia with high expectations. However, they found no acceptance and anger. Soci- 
ety treated them like bad, dangerous and immoral people. Being stigmatized was painful for and life in Serbia had an image of another war. They felt like strangers.

The state had no sympathy for us! We did not voluntarily leave our homes and our lives there! There should have been some reception center. Nobody helped! It was as ones manage. If you leave the house, you have no food. We were all scattered among the family! No job, no home! What can you do? Not all had savings!It is different when you yourself want to go, but you're forced now! We lost our jobs and apartments, we did not know where to go, we did not what to do, we were not we voluntarily accepted!

Politics did everything wrong. They received the help of 1,000 marks for each refugee, and they gave each refugee expired milk powder and oil in the value of 10 marks.

The biggest trauma was possibility of losing their own lives or witnessing murders of other people, and for children in most cases it was leaving the home.

Our childhood was cut off in the worst kind of way! That war was terrible! I was writing songs about war, lost childhood and autumn which will stay in Bosnia forever!

The denial of refugee status is an integral part of privileged identity. I'm not a refugee, I came a little before the war to Bečmen, then in Ugrinovci.I did not feel the war with my body and my soul but I felt the suffering of people close to me, my both families felt, my dad's in Bosnia, and my mother's in Dalmacija. My grandmother who lived with me, was with me in the refugee column that August 95.

I did not volunteer for the Red Cross, because it was not popular for men. (...) We never had refugee status

It ${ }^{t} \mathrm{~s}$ been many years until they were able to realize their desire to visit their country, some of them don't have enough strength to travel there for a few days.

I don't want to come to Croatia, because Croatia is country of hate! I was disappointed with life in Belgrade, but I have never returned to Croatia anymore! Since 26 August 1991 I've never been there and I don't want to go there! I didn't go to funeral of my mother, because one man called me and told me that it was better for me not to go there, because I'm Serb! One Hungarian woman went to Croatia family and listened Croatians who told her that they feel sorry because my father and I left the Croatia, because they would cut, bake and eat us!

I don't want to go to Priština because I can't live there! I went to take the money from the apartment, I had that odd feeling, a wire, a soldier, I 
grabbed a soldier's gun while I signed the contracts, bags, watchtowers, barbed wire, and all behind us.

Twice the Ustasha burned the house, then the Muslims, the Canadians closed their eyes and let them burn the houses. I had pressure from Muslims and Serbs to sell the land. And a Serb in the Federation asked me to sell this land, and I saw that he was working for a percentage. I told them, ,You are shutting the door to us and our return!' But these miserable Serbs want to grab that from you, it looks as if they enjoy civil Rights there. Three times the house was burned in the last century!

Fourteen years later I made it to see the city where I was born and where I spent my early childhood and managed to walk around it. No one lives there anymore, but in Pale, the town near Sarajevo. We visited grandma's grave.

The first time I went to the memorial in 2005, as my mom and dad were buried in the cemetery of Peć. They distroied the images on the tombstones. They were like banging their eyes, as if to dig up their eyes. They crashed down the tombstones, dag, I think they did anything! You could not find the grave! It is not known who was buried. I can not find the graves of people. The church in the cemetery, are all set on fire! Then I visited the monastery of Dečani and the feeling was amazing. You were not there for hundreds of years, my village, my house, it is different to breathe! The monastery in me gives me a special emotion! Whoever comes, they give them a nice welcome. But among the villagers, there were no more Serbs. While we were passing, they were swearing, spitting, throwing stones. They did not let you walk down the street without guards. Some of us had not even visited their place of birth, they wanted to keep that picture how it used to be.

\section{How refugees become religious}

New privileged identity is free of war misery and becomes part of religious society. Main trigger for become religious is cruel reality and reaction of people in new situations. New identity of refugees has orthodox religious experience. Self-identity is created with new experience of religion conversion. Stigmatized people from ,nowhere' become a part of church. New experience is in accordance with Bible and pacifism.

I've tried to answer ,Bread, not rocks!‘

Orthodox and social identity is created with other people who are part of religious community. They are finally adopted as part of society.

I've got icons! 
Through the prism of religion refugees interpreted negative circumstances of their lives as positive ones. The war is seen not like an evil which expelled them from their home towns, but as a trigger which move them towards the church. Instead of saving their own lives and loosing material goods, through religious prism they realize that material world isn't the most important thing, and that struggle for internal life is much more important than fight for profane existence.

Before the war has started we went to church only to light candles. There we lived in the material world. We often chased things we didn't have.

With an orthodox point of view, refugees claim that they forgive everything and that they can participate in international cooperation. During the war they helped each other in buying food, saving lives no matter which nationality it was.

Mujo and Senka, Muslims were very good people and our neighbors! But I' $m$ disgusted with respect to their behavior. I was the athlete of the city and never thought anything bad about anyone, but where I was despised just because I was of another nation, not to speak about how they stole everything that was ours. See the two songs of Jovan Dučić which were banned during that Tito wicked guy, what he sings about the Croats. Recently there was a great linguistic simposia in Zagreb on which a speaker uttered the words were not liked by the audience, and when he came down from the podium a colleague told him, ,You use Serbism in your language;, and he says, ,What, do not drag my tounge, we are already doohickey of the nation. None from Dubrovnik pleaded to speak Croatian, Serbian 97\%, and the other Italian. See how in Croatia kids are scared, A Croat will come to you, not a bogeyman.' Dante pronounced a lot at the expense of the Croats, but their translator all this cut out. Look at what you are doing, but not to talk further, I can not lose my nerves anymore, I' $\mathrm{m}$ no longer objective after all the oppression they have done and all the crimes that remained unpunished.

What was left next to us, we helped them, how we could and after they also helped us when the capitulation is signed. Those who felt that they were not gulity, stayed and we had a very good relationship. We protected them in a couple of occasions, but they were no problem even when there were demonstrations. They were not exposured and were not extremes, at least as far as my neighbors were concerned. But, everyone is fighting for himself, as I' $\mathrm{m}$ fighting for Serbia, they were fighting for their Kosovo. They did not even want to work with us.

Although only a few refugees returned, old people don't feel like a part of Serbia as young do.

We feel like guests here! 
If it was like before, I would come back!

There we restored the house to spend the night. My sister and her husband returned. I am attracted with love for the homeland and to our graves.

Young refugees said that they feel fear only when they return to country where they were expelled from. One of the question was a social distance which was acceptable for them. All refugees agree that they can live with other nationalities in the same country and that they can work with them in the same work places. Being a close friend or a first neighbour with those who expelled them is 50 per cent. Intermarriage is accepted only 28 per cent.

One of my best friends is called Mustafa. (...) It would not be right, but I would agree to a choice of my children.

There's no marriage with Muslims! (laughs) In the company yes, And if the first neighbour is Muslim, I'd have a good distance (...) Oh, oh, I would not like children to socialize with them, just to say polite 'Hello!', even not with the Croats. Grandmother of my husband is Croat and she was a victim. As far as job is concerned it is allright, but anything else - no!

Arrival to Serbia and reactions of Serbian citizens influenced on their pessimistic point of view. The informants said that Serbs don't have enough conscience about their national identity which includes religion and language likewise other nations.

When Jews found out that it would be a war they went from Sarajevo. Jews immediately found out and those who were in the communities much earlier had gone from Sarajevo, and all because of their suffering and they protect their people.

There is a big difference what I think that Belgrade is and what it really is. I was surprised that in Belgrade no one cares about Serbian identity, $\mathrm{Cy}$ rillic, history, how much everything is fake, blaming us that we were expelled from the hometowns. We have a pseudo roots, and our real roots rot. If somebody put me on a plane and disembark on a desert island, there I would be happier. There I ran away from Ustasha not to kill me, but in Belgrade I died twenty to thirty times because of disappointment. When the question to build a monument to the victims of Jasenovac was raised, the government replied that since the Jasenovac was in Croatia, there was already similar monument, and there was no need to raise another monument. Belgrade is anti-Serbian town, go throught Knez Mihailova Street and see what is written in Cyrilic, SANU publishes their issue bulletins in English, and when they are not in English, they are in Latin. Refer to the question of Kosovo. That Hajdin responds that this is not a matter of SANU. Is there anything more tragic and comic than that? 
War misery and a little food were good prerequisite for becoming religious and a good start for abstinence from taboo food during the fast. Those who could be killed are identified with Jesus, Virgin Marry and martyrs.

We started with faith in God. My father put the New Testament in the bag. In Bosnia no one fasted. On Good Friday I rejected ham, but I wanted it.

When I escaped from Sisak, I seriously thought about an absolute, Supreme Lord God. I was convinced that he exists. Later I was baptized here in Belgrade on Ban's Hill to the church of St. George.

(...) The other day I sent the fax, so I hopped into rescue mania, but they said that we had 25000 men, women and children rescued through these children's embassy. When we brought the first group of children to the airport, they made us an ambush, even though there was an agreement that we would be accompanied by police to the airport. And at the airport there was a big transporter which could accept around 800 people, it had no seats, but only holders. We had a deal through general Kukanjac Mićića and we accompanied child to the airport and that they would fly by that plane. That

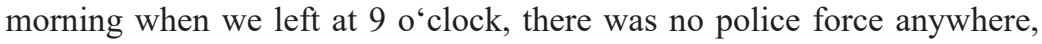
we set off on our own and suddenly Muslims made an ambush, they threw nets accross the roads. We saw men with rifles dressed in camouflage uniforms, I later understood that they just let us pass, if they had wanted to kill us, they would have killed us. We got there, but suddenly we found ourselves between Muslim forces and our army. Boys of 18 years in the JNA. A mother who was feeding the baby was sitting by the window, and she is not moved by the shooting. I was missing two children under the age of 12 years, a boy and a girl. Some awful guy said who we were to take the children from war zone, children ought to have been victims of war. I think horror! I entered with these women and children back into that space. Green Berets would not let us go out, and I made a phone call and got a daughter of Izedbegović. He and his daughter were at that time members of the Children's Embassy. She said she did not know and asked the others who did it. I could not say that the Green Berets shot and I said, ,I do not know who was shooting, but we're going to the airport, and if someone shoot at us I will kill myself, but I am a UNICEF official and it will cause a reaction. I would not kill myself, of course, but it was a moment of despair. We leave and no one shot. I saw how they let people pass throught gate for money and said, ,You can not board on the plane, this is for children"! And the one I was holding for his jacket began to tremble, and at that moment I said who was I to decide who will be saved! I was at the moment looking at the Virgin Marry Milkask who was in her hands breastfeeding a baby Christ! The same day when there was shooting in Sarajevo, in Belgrade Milkask icon was promoted. She was promoted the very same day when all the money was collected and given to Unicef. 
Support of religious officials of the Orthodox Church and confessions to them were key moments of liberation from fear, dismissal of unexplained state and return of security and trust. Conditions of security are absence of fear, suffering and recognition of others who are in some way the same as we are (Danilović-Hristić 2012).

On the first day when I arrived in Belgrade, I went to our Patriarchate". A miracle happened to me, I ve never been in the Patriarchate. I crossed Branko's bridge and asked a man ,Can you take me to the Patriarchate? He said, 'I can!' I look at him, and he was blind and leads me with a white cane, so I interpreted it as if physically blind man leads a spiritually blind man to Patriarchate. I met a priest from Sarajevo, father Perisic was crying like a baby. I told him 'Father, you know how much you were loved by people from Sarajevo', and he then burst into tears and took me to Amfilohije. Because he is very clever and can understand all that. I did not even think of Patriarch Pavle. Up the stairs when I started, came Patriarch Pavle, and I reached out my hand to get his blessing. I kissed his hand and received a blessing. Then I went upstairs. I spoke with Amfilohije, I talked about everything that happened in Sarajevo, and my husband said on the way out that I was wrong that I saved and Muslim children and that one day when Muslims start again, who is going to save our grandchildren. Amfilohije said, ,You did not make any mistake, the Lord said, ,bring the children to me. He gave me his blessing and took me again to Patriarch. So I received three blessing, Patriarch twice and once Amfilohije. It was like a balsam to me.

I had security in church. Now I feel good. We had a priest and that was father Pajsije Hilandarac. He guided us a lot. I went to church regularly, and on lessons of religion. A mother of a female child can say whatever it should be good or not. It is true that we should listen. He prayed, he was first and foremost a great prayer, guard our thoughts and our fears. He watched over us and prayed, all that he interrogated and gave useful and wise advice, and instilled peace. Years later, just seeing his face gives you a sence of peace. His brother was killed because he was a brother of Chilandar priest and it was because of Muslim revenge. When he passed away, my mother saw it, it was very distressing to see. He forgave him as a true Christian, the father, the priest and someone who was a shepherd.

The hermits of St. Save I asked my father Danilo why all this happened to us. He said that anger in people was the reason for this and that to some people no one could help. And he also said that these people here would not endured. (...) The priest always gave us a blessing to go there.

We went to the monastery Rukumija. We had a consolation, as from the father Simeon, and also from other people. Father Simeon said, ,You watch 
out of places and people, where do you not feel good. In every problem, every sorrow, if the Lord takes care of the birds and the lilies how He will not of people. Faith has helped me in exile, religion is in each of us! Nothing is given to a man that can not be endured!

Further integration of the religious community provides security, faith, nation, lack of fear and communication with other people who accept them.

I fast, I'm trying to improve in philosophy, as Nikolaj Velimirović said. I worked as an editor in the library of St. Sava in Zemun, opened the door to the clergy, some have said that it was not my place to be missionar, to what I said that Christ has called us all to be missionaries.

I decided to take Communion, when there was a snake. And my daughter Jovana drove away the snake and there wera always some obstacles, but when I took Communion it was as if I got wings. A spiritual progress, goes slowly as a snail to the ladder. The Prayer Rule of St. Seraphim Sarovski was difficult to me. I was more and more attracted to socializing with older people, and for young people, what to comment just get away from them! But we are far from that materialism, and we are not burdened with that.

My friend was suffering for Rjeka, she was just talking about that. When people ask me ,Do you suffer for Sarajevo? I answer, ,No, we're going to church.' Church simply helps you, to get through it without pain. Lord gives this power, this blessing. The church helped me not only to forget the sadness, the church helps you to forget any grief. I read, Who goes to church, does not suffer' or something like that. Everyone who is thirsty of love comes to church!

God as a synonym for love is the main trigger force for refugees to overcome all the hardships and misery that had come upon them.

In one night grenades blare, I was like above the ground and below me there was Bosna I saw that Drina run as if it was red-hotted, the same Sava and Una. There were a lot of clouds and rumbling, and as if I asked someone 'Who can stop this?' And then I heard that 'Love will stop it' but I never thought that the love was the God! I was on the verge of freaking out! One mentally terible effort! No one could Diminish it, it was so deep! It strengthened my faith, all that horror! I started to do humanitarian work, otherwise I would not have stayed sane. I found salvation in that, helping other people! Giving myself to the others pulled me out of this terrible condition as well as going to church on liturgy!

The devil as a synonym for evil and enmity has become the opposite of what they felt and what they want in life. 
Let them go with dear God, I'm not a man of hate. Hate primarily comes from the devil. I'm not the one who puts himself on the devil's side, which is the side of hate.

Religion is an indicator of national identity. The whole system of their most elemental values, originated from orthodoxy, regardless of what they were intergrisana believers. In contrast to their attitude towards religion, expulsion of refugees were osmišljenjno in accordance with the religions of other nations so that all the battles have been marked religious holidays that are celebrated ,They'.

Communism is rejected and you return to your religion. Saint places are being renewed, people are returning to church. And a lot of people turned themselves to the religion. The church was not so pushy. You have to know from which religion you are and where you belong to. To have the family saint and church that you belong to. I think, nation. A lot of people accepted all these. On March 17 the Monastery of Dečani were not touched, they were immediately protected. Right away, the Italians occupied the monastery of Visoki Dečani and the Peć Patriarchate. Devič was on fire! They could not destroy Gracanica! Churches were destroyed and burned. 135 religious buildings were destroyed. Uroševac, Mitrovica, where there are no more Serbs. Uniquely, the church and the mosque next to each other, and the church burnt down (he laughs). So we did not destroy theirs during the war, and they burned as soon as they come (he laughs again) and so on. The only who protected the sacred objects were the Italians. There were Italians, Germans, then came the others, Swedes, Germans. Pristina was hold by the Swedes and Norwegians.

I accepted the renewal of monument on which there was a large cross. We were a wealthy family and they restored the cross, higher than two meters. Here lies Jovo Tubić, he is my great-grandfather, born in 1850, he moved into eternity on 21 October 1918 . Old calendar and nothing more. Our godparents married us in the church, and now this monument of my great-grandfather. (...) Everybody wants to go to Europe, and no one want not talk with the poor, to help the poor. It's not friendly towards a man-worker, this capitalism is nowhere cruel like here! But our faith teaches us not to grumble when they reduce our salaries or when we have no money for food. I noticed that Muslims like to read Dostoevsky, and that soul also wants Orthodoxy, it is one more proof! This is the work of God, that we are precipitated, and then risen. All these roads have sideways, but a man should be a believer, but not a fanatic! (he laughs). Our eyes opened, we stopped running for the material and started searching for more spiritual. We married in church, and that church was built by us refugees! So that we contribute to the country that received us! 
Respondents do not want to be what happened to them happen to any other nation, arguing that the best way of reconciliation.

The man just wants to go forward, to look on the bright, but it will always come back around as he lived.

\section{Conclusion}

Research was conducted in field work, central attention was focused on language, and a war is observed as a set of dynamic interaction. The informants use synonyms like ,game', ,war circus' etc. The plot starts with enemy attacks and refugees reactions. The narrative is story of the past and for refugees it makes sense. The plot is consisted of enemy attack and reaction of refugees. After the attack life becomes confusion and it is impossible to fulfill meaningful further life story. Religion is seen as a matrix of meaning. Social construction is consisted of people who participants freely choose. Emotions are intolerant with the breaking God's rules like killing, stealing etc. The refugees didn't have enough choice and like the subject they were in some position. The refugees feel disappointed and cheated in interaction with enemies. Self-narrative is the only truth which they have. The refugees speak in the way in which the first part of sentence is always positive and second part of sentence is always negative. Negative part of sentence is time between two positive events. For example the first is enemy attack, then refugees react. If there is no positive outcome the refuges will suffer. The refugees need to show positive aspects of behavior in war. On their way they always have negative situations which they have to overcome, such as communism or snake on the road which leads to church. With narrative they create themselves and the world around them. Their stories follow their own culture heritage. Characteristics of the main figures are brave and help others. Furthermore the refugees identify themselves with martyrs and religious officials. Significant others are religious officials who accept them and have sincere communication with them. The refugees become a part of orthodox culture and nation. The refuges feel post-traumatic stress disorder. Depending on degree of exposure they have nightmares, depression and high degree of nervousness. Serbs from Bosnia and Herzegovina didn't pay attention to their ethnic identity. Serbs from Croatia pay attention to their ethnic identity and rites like: baptism, engagement and wedding. Ethnic identification starts with beginning of the war and make distance from anything which is not a part of , we' group. International cooperation still exists in the war when it comes with friends in ecumenism. Man have stronger ethnic at- 
tachment to religion, national marriages, Cyrillic and state than women. In addition to ethnic identity, informants feel and general human attachment and concern for the public good and are willing to cooperate for the international welfare. In group, we' refugees consider religious community and friends no matter which nationality they belong to. In group ,other' are enemies who expelled and discriminated them. The refugees see nation like a traditional culture, not like a state. After the analog and digital principle of systematization internal positive people are believers, internal negative inhumane Serbian people, and positive external friends of other nations, while the external negative those who wanted an ethnically pure states and caused the war. The experience of refugees is different compared to all the others who have experienced the war only through the media.

Nicholas played with Milan and bought him a gun and said that they would go to war. When Milan said that there would be a war and that he would shoot, I told him, Your mum has something to tell you. War is the worst thing that can happen to people. Your mum has witnessed the war and your dad was just watching it on TV!'

\section{Literature}

Даниловић-Христић, Наташа. 2012. Безбедност жена у савременом јавном простору Београда и допринос феминистичких студија аспекту урбане безбедности. Токови истиорије 3/2012 381-404

Дејзинг, Гер. 2005. Религија и идентитет на Косову. Београд: XX vek

Kuburić, Zorica. 2010a. O mogućnostima izgradnje međusobnog poverenja na Balkanu. y Religija, duhovnost i posttraumatsko sećanje, ur. Nikola Knežević, Srđan Sremac и Zoran Grozdanović, 357-374. Rijeka: Ex Libris

Кубурић, Зорица. 2010b. Религиозност у Србији 2010. Београд: Хришћански Културни Центар

Nedeljković, Saša. 2007. Čast, krv i suze. Beograd: Zlatni zmaj

Opačić, Goran. Vidaković, Ivana. Vujadinović, Branko (ur.). 2005. Život u posleratnim zajednicama. Beograd: IAN Međunarodna mreža pomoći

Pavlović, Jelena. Džinović, Vladimir. Milošević, Nikoleta. 2006. Teorijske pretpostavke diskurzivnih i narativnih pristupa u psihologiji. Psihologija vol 39 (4) 365-381

Ribić, Vladimir. 2006. Stef Jansen. Antinacionalizam. Etnoantropološki problemi $1215-$ 217

Ribić, Vladimir.2007. Američki antropolozi u ratu. Antropologija no 3. 40-48

Sremac, Srđan. Radić, Tatjana. 2010a. Bio sam navučen. Transformativno iskustvo bivših zavisnika: Uloga narativnog identiteta, religijske konverzije i socijalne podrške u procesu rehabilitacije. Antropologija 10 sv. 3 49-71

Sremac, Srđan. Beuk, Sergej. 2010b. Opasna sjećanja i pomirenje: kontekstualna promišljanja o religiji u postkonfliktnom društvu. Y Religija, duhovnost i posttraumat- 
sko sećanje, ur. Nikola Knežević, Srđan Sremac и Zoran Grozdanović, 269-284. Rijeka: Ex Libris

Жикић, Бојан. 2011. Друштвени чиниоци здравствене вулнерабилности

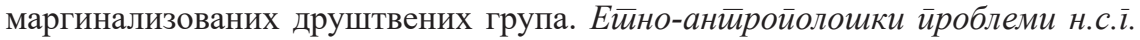
6. Св. 3

Жикић, Бојан. 2007. Антрополошко проучавање маргиналних друштвених група: методологија теренског рада. Гласник Етнографског музеја у Београду но 71 (71) $39-52$

Жикић, Бојан. 2005. Етнокултурна дуалност и етнички стереотипи. ГЕИ САНУ LIII $67-80$

Жикић, Бојан. 1997. Свети Сава као морални трикстер. Свети Сава у усменом предању Срба из БиХ. ГЕИ САНУ књ. XLVI 123-128 


\section{Ања Абрамовић}

maanjaabramovic@gmail.com

\section{СРПСКЕ ПРАВОСЛАВНЕ ИЗБЕГЛИЦЕ: АНАЛИЗА НАРАТИВА}

\section{Резиме:}

Pag се бави обновом и оиравослављивањем урушеної ияенииииетей избеїлииа. Православно-соиијална йодрика је кључни асиекит ирревазилажења иррауме. Избеїлице се иоостиовећују са релийијским функиионерима. Иниееірација у верску

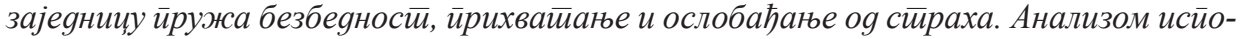
весии и иокушавамо gа gубље сайлеgамо кулииурни шок, йсихолошку трауму и gуховну иирансформацију избеїлица.

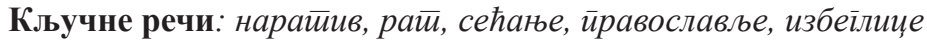

